\title{
Effect of Priming Agents on Seed Germination of Three Corn Species
}

\author{
*OLORUNMAIYE, KS; OLATUNJI, IO \\ Department of Plant Biology, University of Ilorin, Ilorin, Nigeria \\ *Correspondence Email: Olorunmaiyestephen@gmail.com
}

\begin{abstract}
This study determines the effect of different priming agents (water, sodium chloride, potassium nitrate and calcium sulphate) on seed germination and sprout development in Guinea corn (Sorghum bicolor), millet (Pennisetum glaucum) and popcorn maize (Zea mays var everta). Different concentrations of the priming agents (5, 10,15 and $20 \mathrm{~g} / \mathrm{l}$ ) were used for a period of 24 hours and the primed seeds planted on Petri dishes at the same time. At the end of five days germination, effects of each of the priming agents were as follows; (water: $2.67 \pm 0.00,13.67 \pm 0.00$ and $6.33 \pm 0.00) ;(\mathrm{NaCl}: 3.84 \pm 0.70,12.08 \pm 0.74$ and $2.75 \pm 0.96) ;\left(\mathrm{KNO}_{3}: 3.17 \pm 0.79,11.67 \pm 0.27\right.$ and $\left.2.75 \pm 0.96\right) ;$ $\left(\mathrm{CaSO}_{4}: 4.25 \pm 1.66,13.50 \pm\right.$ and 5.25 \pm 0.32$)$ respectively for popcorn maize, guinea corn and millet germination. Priming of seeds generally increased germination and caused a rapid increase in growth of plumule and root. It was discovered that all the priming agents supported germination with calcium sulphate topmost in some cases among them. All the priming agents used were effective in aiding seed germination in popcorn maize and sorghum more than in millet.
\end{abstract}

\section{DOI: https://dx.doi.org/10.4314/jasem.v22i8.27}

Copyright: Copyright $@ 2018$ Olorunmaiye and Olatunji. This is an open access article distributed under the Creative Commons Attribution License (CCL), which permits unrestricted use, distribution, and reproduction in any medium, provided the original work is properly cited.

Dates: Received: 18 May 2018; Revised: 17 July: 2018; Accepted: 05 August 2018

Keywords: germination, seed, seed priming, seedling development

Seed germination depends on both internal and external conditions. The most important external factors include temperature, water, oxygen and sometimes light or darkness (Raven et. al., 2005). The pre-sowing treatments caused initiation of early metabolic processes and the re-drying of seeds arrest, but do not reverse the initial stages of germination so that the availability of suitable conditions for the time taken to germinate is reduced (Hosseein et al., 2011). Rapid embryo growth resulted when the obstacle to germination was removed (Basra et al., 2003). Seed priming is used to increase germination (Farooq et al., 2006 and 2007). Seed priming is a way of regulating the germination process by managing the temperature and seed moisture content. The seed is taken through the first biochemical processes within the initial stages of germination and enhances uniformity (Stacy, 2016). In seed priming, seeds are hydrated in various priming agents to initiate the metabolic processes of germination. Seed priming is a type of seed enhancements, thereby improving a crop yield and quality. Priming induces biochemical changes in seed which leads to increase in germination rate, emergence and seedling vigor which results in fast germination and rapid development of the root system (Seed Quest, 2013). Priming helps to overcome or alleviate phytochrome induced dormancy in plant; decreases the time necessary for germination and emergence; improves the stand uniformity; aiding in production management and increasing the chance for uniformity at harvest. Priming allows seedling to control their water usage, eliminate or greatly reduce the amount of seed borne fungi and bacteria (Seed Quest, 2013). Farooq et al., (2007) reported that plants from primed seeds grow more vigorously and flowered earlier. Also, Farooq et al., (2005) observed that fresh seeds of different tomato cultivars primed in sodium chloride and potassium nitrate performed better than untreated seeds. Popcorn, also known as "popping corn", is a type of corn (maize, Zea mays var. everta) that expands from the kernel and puffs up when heated. Corn is able to pop because, like amaranth grain, sorghum, quinoa and millet, its kernels have a hard moisture-sealed hull and a dense starchy interior. This allows pressure to build up inside the kernel until explosive "pop" results. Some strains of corn are cultivated specifically as popping corns (Wikipedia, 2013). Millets, like sorghum, are predominantly starchy. The protein content is comparable to that of wheat and maize. Pearl and little millet are higher in fat. Millets are also relatively rich in iron and phosphorus. The bran layers of millets are good sources of B-complex vitamins (Mcdonough, 2000). Sorghum is one of the most important cereals in West Africa. It is also grown mainly in the semi-arid areas of the tropics and subtropics and in most West African countries, sorghum alone accounts for $50 \%$ of the total cereal crop land area. It is one of the principal sources 
of energy, protein, vitamins and minerals for millions of the poorest people in the regions (FAO, 2005). The objectives of this experiment were to evaluate the effect of different seed priming agents with different concentrations on seed germination and seedling development of Sorghum bicolor, Pennisetum glaucum, Zea mays var everta and evaluate the response of crops to different seed priming agents.

\section{MATERIALS AND METHODS}

Seeds of Sorghum (Sorghum bicolor), popcorn maize/popping maize (Zea mays var.everta) and millet (Pennisetum glaucum) were obtained from an agricultural store in Ojaoba market in Ilorin, Kwara State, Nigeria. Priming agents which include calcium sulphate $\left(\mathrm{CaSO}_{4}\right)$, potassium nitrate $\left(\mathrm{KNO}_{3}\right)$ and sodium chloride $(\mathrm{NaCl})$ were obtained in a laboratory equipment shop at Taiwo road, Ilorin, Kwara State, Nigeria. Four concentrations $(5,10,15$ and 20 g/l) and control (distilled water) of the salts of the priming agents were prepared. Fifty seeds of each of the test seeds were soaked in $200 \mathrm{ml}$ of each of the concentrations for 24hours in sample bottles after which they were removed and rinsed thoroughly in distilled water (Rajpar et al.; 2006 and Toklu et al.; 2015), thereafter 15 seeds were planted on moistened filter paper in each of the already labeled petri dishes in the Plant physiology laboratory of the Department of Plant Biology, University of Ilorin, Ilorin, Nigeria. Each of the treatments was replicated thrice and arranged in randomized form on the laboratory table. Germination count was taken daily for five days while Shoot and root lengths were taken five days after the germination. Data collected were subjected to analysis of variance using SPSS statistical software (SPSS Inc. Chicago. USA, version 20). Duncan's New Multiple Range Test (DNMRT) at 0.05 level of probability was used to separate the means.

\section{RESULTS AND DISCUSSION}

Effect of various priming agents on germination rate are shown on tables below. The rate of germination was affected in all the concentrations of the priming agents.

Table1: Effect of Calcium Sulphate $\left(\mathrm{CaSO}_{4}\right)$ on the Germination of Sorghum bicolor

\begin{tabular}{llllll}
\hline $\mathrm{CaSO}_{4}(\mathrm{~g} / \mathrm{l})$ & Day1 & Day2 & Day3 & Day4 & Day5 \\
\hline Control & $11.33^{\mathrm{ab}}$ & $12.00^{\mathrm{a}}$ & $11.00^{\mathrm{b}}$ & $11.33^{\mathrm{b}}$ & $13.67^{\mathrm{a}}$ \\
5 & $10.00^{\mathrm{b}}$ & $12.00^{\mathrm{a}}$ & $12.00^{\mathrm{ab}}$ & $12.33^{\mathrm{ab}}$ & $12.33^{\mathrm{a}}$ \\
10 & $14.00^{\mathrm{a}}$ & $14.33^{\mathrm{a}}$ & $14.33^{\mathrm{a}}$ & $14.67^{\mathrm{a}}$ & $14.67^{\mathrm{a}}$ \\
15 & $12.33^{\mathrm{ab}}$ & $12.67^{\mathrm{a}}$ & $12.67^{\mathrm{ab}}$ & $13.00^{\mathrm{ab}}$ & $13.33^{\mathrm{a}}$ \\
20 & $11.33^{\mathrm{ab}}$ & $13.00^{\mathrm{a}}$ & $13.33^{\mathrm{ab}}$ & $13.33^{\mathrm{ab}}$ & $13.67^{\mathrm{a}}$ \\
\hline
\end{tabular}

Table2: Effect of Calcium Sulphate $\left(\mathrm{CaSO}_{4}\right)$ on the Germination of Pennisetum glaucum

\begin{tabular}{llllll}
\hline $\mathrm{CaSO}_{4}(\mathrm{~g} / \mathrm{l})$ & Day1 & Day2 & Day3 & Day4 & Day5 \\
\hline $\mathrm{Control}$ & $0.00^{\mathrm{b}}$ & $0.00^{\mathrm{b}}$ & $2.33^{\mathrm{a}}$ & $5.33^{\mathrm{a}}$ & $6.33^{\mathrm{a}}$ \\
5 & $4.00^{\mathrm{ab}}$ & $3.67^{\mathrm{ab}}$ & $5.00^{\mathrm{a}}$ & $5.00^{\mathrm{a}}$ & $5.00^{\mathrm{a}}$ \\
10 & $4.33^{\mathrm{ab}}$ & $4.33^{\mathrm{ab}}$ & $5.00^{\mathrm{a}}$ & $5.33^{\mathrm{a}}$ & $5.33^{\mathrm{a}}$ \\
15 & $5.33^{\mathrm{a}}$ & $5.33^{\mathrm{a}}$ & $5.33^{\mathrm{a}}$ & $5.33^{\mathrm{a}}$ & $5.67^{\mathrm{a}}$ \\
20 & $3.67^{\mathrm{ab}}$ & $3.67^{\mathrm{ab}}$ & $4.66^{\mathrm{a}}$ & $5.33^{\mathrm{a}}$ & $5.00^{\mathrm{a}}$ \\
\hline \multicolumn{2}{l}{ Values carrying the same letter $(s)$ along the same column are not significantly different at $(p<0.05)$}
\end{tabular}

Table3: Effect of Calcium Sulphate $\left(\mathrm{CaSO}_{4}\right)$ on the Germination of Zea mays var everta

\begin{tabular}{llllll}
\hline Conc CaSO4(g/l) & Day1 & Day2 & Day3 & Day4 & Day5 \\
\hline Control & $0.00^{\mathrm{b}}$ & $1.67^{\mathrm{b}}$ & $2.00^{\mathrm{b}}$ & $2.67^{\mathrm{b}}$ & $2.67^{\mathrm{a}}$ \\
5 & $0.67^{\mathrm{b}}$ & $2.00^{\mathrm{b}}$ & $2.67^{\mathrm{ab}}$ & $2.67^{\mathrm{b}}$ & $2.67^{\mathrm{a}}$ \\
10 & $4.00^{\mathrm{a}}$ & $5.00^{\mathrm{a}}$ & $5.00^{\mathrm{a}}$ & $5.33^{\mathrm{ab}}$ & $5.33^{\mathrm{a}}$ \\
15 & $2.33^{\mathrm{ab}}$ & $5.33^{\mathrm{a}}$ & $5.33^{\mathrm{a}}$ & $6.00^{\mathrm{a}}$ & $6.00^{\mathrm{a}}$ \\
20 & $1.00^{\mathrm{b}}$ & $2.67^{\mathrm{ab}}$ & $2.67^{\mathrm{ab}}$ & $2.67^{\mathrm{a}}$ & $3.00^{\mathrm{a}}$ \\
\hline \multicolumn{5}{l}{ Values carrying the same letter(s) along the same column are not significantly different at $(p<0.05)$}
\end{tabular}

Calcium Sulphate Treatment: Effect of $\mathrm{CaSO}_{4}$ on the germination of Sorghum bicolor was significant among the various concentrations, in day1, 3 and 4 but not in day 2 and 5 . Concentration of $10 \mathrm{~g} / 1$ had the highest germination counts throughout the period of the experiment (Table 1).Values carrying the same letter(s) along the same column are not significantly different at $(\mathrm{p}<0.05)$.

Germination rate response of Pennisetum glaucum to Calcium sulphate was significantly different at different concentrations at day 1 and 2 but not in day 3,4 , and 5 . All the concentrations enhanced early germination than the control treatment at day 1 and 2. Concentration of $15 \mathrm{~g} / \mathrm{l}$ of $\mathrm{CaSO} 4$ consistently enhanced higher germination than the rest concentrations (Table2).

This observed increase in germination was in agreement with the earlier reports of Faroog et al., (2005 and 2007) that priming agents increase germination and growth development in seeds especially tomato cultivars.

The effect of calcium sulphate on the germination of Zea mays var everta was highest in $15 \mathrm{~g} / \mathrm{l},(6.00)$. There were significant differences at day 1-4 but not in day 5 (Table 3). Calcium sulphate has its lowest germination rate at 5 and $20 \mathrm{~g} / \mathrm{l}$ while, $15 \mathrm{~g} / \mathrm{l}$ was more effective than other levels of concentration (Table 3).

Potassium Nitrate Treatment: There were no significant differences among the various concentrations of potassium nitrate and the control treatment, however, concentration of $10 \mathrm{~g} / \mathrm{l}$ and the control treatment were at par and in some cases control treatment produced higher mean germination (Table 4). 
Table 4: The Effect of Potassium Nitrate $\left(\mathrm{KNO}_{3}\right)$ on Germination of Sorghum bicolor.

\begin{tabular}{llllll}
\hline $\mathrm{KNO}_{3}(\mathrm{~g} / \mathrm{l})$ & Day1 & Day2 & Day3 & Day4 & Day5 \\
\hline Control & $11.33^{\mathrm{a}}$ & $12.00^{\mathrm{a}}$ & $11.00^{\mathrm{a}}$ & $11.33^{\mathrm{a}}$ & $13.67^{\mathrm{a}}$ \\
5 & $9.33^{\mathrm{a}}$ & $10.33^{\mathrm{a}}$ & $11.33^{\mathrm{a}}$ & $11.67^{\mathrm{a}}$ & $12.00^{\mathrm{a}}$ \\
10 & $11.00^{\mathrm{a}}$ & $11.00^{\mathrm{a}}$ & $11.67^{\mathrm{a}}$ & $11.67^{\mathrm{a}}$ & $11.67^{\mathrm{a}}$ \\
15 & $7.00^{\mathrm{a}}$ & $10.00^{\mathrm{a}}$ & $10.33^{\mathrm{a}}$ & $10.33^{\mathrm{a}}$ & $11.33^{\mathrm{a}}$ \\
20 & $10.33^{\mathrm{a}}$ & $10.33^{\mathrm{a}}$ & $11.00^{\mathrm{a}}$ & $11.33^{\mathrm{a}}$ & $11.67^{\mathrm{a}}$ \\
\hline
\end{tabular}

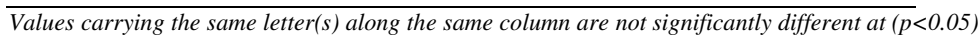

Table 5: The Effect of Potassium Nitrate on Germination of Zea mays var everta

\begin{tabular}{llllll} 
Conc. $\mathrm{KNO}_{3}(\mathrm{~g} / \mathrm{l})$ & Day1 & Day2 & Day3 & Day4 & Day5 \\
\hline Control & $0.00^{\mathrm{a}}$ & $0.00^{\mathrm{a}}$ & $2.33^{\mathrm{a}}$ & $5.33^{\mathrm{a}}$ & $6.33^{\mathrm{a}}$ \\
5 & $0.33^{\mathrm{a}}$ & $2.33^{\mathrm{a}}$ & $2.33^{\mathrm{a}}$ & $2.67^{\mathrm{a}}$ & $2.67^{\mathrm{a}}$ \\
10 & $1.33^{\mathrm{a}}$ & $3.67^{\mathrm{a}}$ & $2.33^{\mathrm{a}}$ & $3.67^{\mathrm{a}}$ & $3.67^{\mathrm{a}}$ \\
15 & $0.67^{\mathrm{a}}$ & $3.67^{\mathrm{a}}$ & $3.67^{\mathrm{a}}$ & $4.00^{\mathrm{a}}$ & $4.00^{\mathrm{a}}$ \\
20 & $0.33^{\mathrm{a}}$ & $2.00^{\mathrm{a}}$ & $2.33^{\mathrm{a}}$ & $2.33^{\mathrm{a}}$ & $2.33^{\mathrm{a}}$
\end{tabular}

Values carrying the same letter(s) along the same column are not significantly different at $(\mathrm{p}<0.05)$

\begin{tabular}{llllll}
\multicolumn{6}{c}{ Table 6: The Effect of Potassium Nitrate on the Germination of Pennisetum glaucum } \\
\hline Conc.KNO3(g/l) & Day1 & Day2 & Day3 & Day 4 & DAY5 \\
\hline Control & $0.00^{\mathrm{b}}$ & $0.00^{\mathrm{a}}$ & $2.33^{\mathrm{a}}$ & $4.00^{\mathrm{ab}}$ & $6.33^{\mathrm{a}}$ \\
5 & $2.67^{\mathrm{a}}$ & $1.33^{\mathrm{a}}$ & $1.33^{\mathrm{a}}$ & $1.67^{\mathrm{a}}$ & $1.67^{\mathrm{b}}$ \\
10 & $0.00^{\mathrm{b}}$ & $2.33^{\mathrm{ab}}$ & $2.67^{\mathrm{a}}$ & $2.67^{\mathrm{a}}$ & $2.67^{\mathrm{b}}$ \\
15 & $0.00^{\mathrm{b}}$ & $2.67^{\mathrm{a}}$ & $2.67^{\mathrm{a}}$ & $2.67^{\mathrm{a}}$ & $2.67^{\mathrm{b}}$ \\
20 & $0.67^{\mathrm{b}}$ & $3.33^{\mathrm{a}}$ & $4.00^{\mathrm{ab}}$ & $4.00 .^{\mathrm{ab}}$ & $4.00^{\mathrm{ab}}$ \\
\hline
\end{tabular}

Values carrying the same letter( $(s)$ along the same column are not significantly different at $(p<0.05)$

Table7: Effect of Sodium Chloride on germination of Millet (Pennisetum glaucum)

\begin{tabular}{llllll}
\hline Conc. $\mathrm{NaCl}(\mathrm{g} / \mathrm{l})$ & Day1 & Day2 & Day3 & Day4 & Day5 \\
\hline Control & $0.00^{\mathrm{b}}$ & $0.00^{\mathrm{b}}$ & $2.33^{\mathrm{a}}$ & $5.33 \mathrm{a}$ & $6.33^{\mathrm{a}}$ \\
5 & $0.33^{\mathrm{b}}$ & $1.33^{\mathrm{ab}}$ & $1.33^{\mathrm{a}}$ & $1.67^{\mathrm{b}}$ & $1.67^{\mathrm{b}}$ \\
10 & $2.33^{\mathrm{ab}}$ & $2.33^{\mathrm{ab}}$ & $2.67^{\mathrm{a}}$ & $2.67^{\mathrm{b}}$ & $2.67^{\mathrm{b}}$ \\
15 & $2.33^{\mathrm{ab}}$ & $2.67^{\mathrm{a}}$ & $2.67^{\mathrm{a}}$ & $2.67^{\mathrm{b}}$ & $2.67^{\mathrm{b}}$ \\
20 & $3.33^{\mathrm{a}}$ & $3.33^{\mathrm{a}}$ & $3.33^{\mathrm{a}}$ & $4.00^{\mathrm{ab}}$ & $4.00^{\mathrm{ab}}$ \\
\hline
\end{tabular}

Values carrying the same letter(s) along the same column are not significantly different at ( $p<0.05$ ),

Table 8: Effect of Sodium Chloride on germination of Sorghum bicolor

\begin{tabular}{llllll}
\hline Conc.NaCl $(\mathrm{g} / \mathrm{l})$ & Day1 & Day2 & Day3 & Day4 & Day5 \\
\hline Control & $11.33^{\mathrm{a}}$ & $12.00^{\mathrm{ab}}$ & $11.00^{\mathrm{b}}$ & $11.33^{\mathrm{b}}$ & $13.67^{\mathrm{a}}$ \\
5 & $10.67^{\mathrm{a}}$ & $11.00^{\mathrm{b}}$ & $11.00^{\mathrm{b}}$ & $11.33^{\mathrm{b}}$ & $11.33^{\mathrm{c}}$ \\
10 & $11.00^{\mathrm{a}}$ & $12.00^{\mathrm{ab}}$ & $12.00^{\mathrm{ab}}$ & $12.33^{\mathrm{ab}}$ & $12.33^{\mathrm{bc}}$ \\
15 & $6.33^{\mathrm{b}}$ & $11.00^{\mathrm{ab}}$ & $11.00^{\mathrm{b}}$ & $11.67^{\mathrm{b}}$ & $11.67^{\mathrm{c}}$ \\
20 & $12.00^{\mathrm{a}}$ & $12.67^{\mathrm{a}}$ & $12.67^{\mathrm{a}}$ & $13.00^{\mathrm{a}}$ & $13.00^{\mathrm{ab}}$ \\
\hline
\end{tabular}

Values carrying the same letter(s) along the same column are not significantly different at $(p<0.05)$

Table 9: Effect of Sodium Chloride on germination of Zea mays var. everta

\begin{tabular}{llllll}
\hline Conc. $\mathrm{NaCl}(\mathrm{g} / \mathrm{l})$ & Day1 & Day2 & Day3 & Day4 & Day5 \\
\hline Control & $0.00^{\mathrm{a}}$ & $1.67^{\mathrm{a}}$ & $2.00^{\mathrm{a}}$ & $2.67^{\mathrm{a}}$ & $2.67^{\mathrm{a}}$ \\
5 & $2.67^{\mathrm{a}}$ & $4.33^{\mathrm{a}}$ & $4.67^{\mathrm{a}}$ & $4.67^{\mathrm{a}}$ & $4.67^{\mathrm{a}}$ \\
10 & $1.67^{\mathrm{ab}}$ & $4.00^{\mathrm{a}}$ & $4.00^{\mathrm{a}}$ & $4.00^{\mathrm{a}}$ & $4.00^{\mathrm{a}}$ \\
15 & $1.00^{\mathrm{ab}}$ & $2.67^{\mathrm{a}}$ & $2.67^{\mathrm{a}}$ & $2.67^{\mathrm{a}}$ & $3.00^{\mathrm{a}}$ \\
20 & $1.33^{\mathrm{ab}}$ & $3.33^{\mathrm{a}}$ & $3.67^{\mathrm{a}}$ & $3.67^{\mathrm{a}}$ & $3.67^{\mathrm{a}}$ \\
\hline
\end{tabular}

Values carrying the same letter(s) along the same column are not significantly different at $(p<0.05)$

Priming with potassium nitrate, popcorn maize did not show significant differences, however, there was early germination in all its concentrations than the control treatment (Table 5). Concentration of 15 $\mathrm{g} / \mathrm{l}$ of $\mathrm{KNO}_{3}$ was better than all others of its concentrations on the germination of Zea mays var everta (Table 5). Response of Pennisetum glaucum to KNO3 was early germination and higher germination rate up to day-4 after which the control experiment gave the highest mean germination (Table 6). Tables 7-9, showed the effects of Sodium chloride on germination of millet, guinea corn and maize. These results agreed with the earlier observation of Maher et al.;(2013) that seed priming with sodium chloride increased final percentage germination, germination speed and radicle length over the non-primed treatment of
Tunisian Fenugreek (Trigonella foenum-graecum L.). Sodium chloride concentration of $20 \mathrm{~g} / \mathrm{l}$ was more effective in the germination rate of Sorghum bicolor than the other concentrations and the control until day- 4 and 5 when control was highest. Sodium chloride priming effect on the germination rate of popcorn maize was not as pronounced as it is in S. bicolor. Concentration $5 \mathrm{~g} / \mathrm{l}$ caused an increase in germination rate compared to other concentrations and the control (Table 9). All priming treatments significantly increased the germination rate of sorghum bicolor, this finding was in accordance with the findings of Basra et al., (2003) who reported improvement in germination percentage by using seed priming techniques. Priming with Calcium Sulphate significantly improved germination rate over other treatments.

Priming with water was observed be very adequate in Millet (Pennisetum glaucum) which showed the highest germination rate. This was followed by priming with Calcium Sulphate, Sodium chloride and least in Potassium Nitrate.The germination of Popcorn maize seeds was less at high concentration of 20 $\mathrm{g} / \mathrm{l}$ of $\mathrm{KNO}_{3}$ but not at lower concentrations of $15 \mathrm{~g} / \mathrm{l}$ and below which enhanced good germination. The highest germination rate was observed in treatments with Calcium Sulphate and Sodium Chloride.

Conclusion: From this study, it can be concluded that effect of the priming agents used caused a positive increase in germination rate. Calcium sulphate, potassium nitrate, and sodium chloride were effective in priming of seeds. Calcium Sulphate, had an outstanding effect on the test crops over all other priming agents used as treatments. 


\section{REFERENCES}

Basra, SMA; Ehsanullah, EAW; Cheema, M A; Afzal, I (2003). Effect of storage on growth and yield of primed canola seeds (Brassica napus). Int. J. Agric. and Biol. 5:117-120.

Demir, H; Mavi, K (2004).Seed priming of male sterile musk melon Cucumis melo (L) for low temperature germination. Seed Sci. Tech. 23(4):881-884.

FAO, (2005). The state of food insecurity in the world. Pp 92- 102

Farooq, M; Basra, SMA; Saleem, BA; Nafees, M; Chishti, SA (2005a). Enhancement of tomato seed germination and seedling vigour by osmopriming. Pak. J. Agric. Sci., 42(3-4): 36-41.

Farooq, M; Basra, SMA; Hafeez, K; Ahmad, N (2005b). Thermal hardening: a new seed vigor enhancement tool in rice. J. Integr. Plt. Biol. 47: 187-193.

Farooq, M; Basra SMA; Cheema, MA; Afzal, I (2006). Integration of pre-sowing soaking, chilling and heating treatments for vigor enhancement in rice (Oryza sativa L.). Seed Sci. and Tech., 34, 521-528.

Farooq, M; Basra, SMA; Ahma, N (2007). Improving the performance of transplanted rice by seed priming. Plt. Gr. Reg.; 51, 129-137.
Hosseein, AF; Karsa, M (2011). Effect of hydropriming on seedling vigour in Basil (Ocimum basilicum L.) under salinity conditions. $A d v$. in environ. Biol., 5 (5):828-833.

Maher, S; Fraj, H; Cherif, H (2013). Effect of $\mathrm{NaCl}$ Priming on Seed Germination of Tunisian Fenugreek (Trigonella foenum-graecum L.) Under Salinity Conditions. J. Stress Phy. Bioch 9 (2) $86-96$

McDonough, CM; Rooney, LW; Serna-Saldivar, SO (2000)."The Millets". Food Sci. and Tech.: Handbook of Cereal Science and Technology (CRC Press) 99:177-210.

Rajpar,I; Khanif, YM; Memon, AA (2006). Effect of Seed Priming on Growth and Yield of Wheat (Triticum aestivum L.) Under Non-Saline Conditions. International J. of Agric. Res., 1: 259-264.

Raven, PH; Ray, FE. Susan, EE (2005). Biology of Plants, 7th Edition. New York: Freeman WH. and Company Publishers. pp. 504-508.

Stacy, D (2016). Seed priming \& Uncategorized. Germains Seed Tech. Jan. Ed.2016

Toklu, F; Baloch, FS; Karakoy, T; Özkan, H (2015). Effects of different priming applications on seed germination and some agromorphological characteristics of bread wheat (Triticum aestivum L.) Turk. J. Agric. For. (2015) 39: 1005-1013 